\title{
Intellectual Capital and Bank Performance in Nigeria: An Empirical Analysis Using Pragmatic Models
}

\author{
S. J. Inyada, PhD \\ Department of Accounting \\ Kogi State University \\ Anyigba-Nigeria
}

\begin{abstract}
There have been some conflicting results on the importance and relationship between intellectual capital and organizational performance especially in Nigeria. While some scholars agree that intellectual capital relates positively and significantly with organizational financial performance and as such accord organizations competitive edge over others, others believe that there are no relationships between intellectual capital and organizational performance and that physical assets still maintain the key determinants of organizational financial performance. Intellectual capital as the knowledge based equity of organizations has attracted a significant amount of practical interest. Although the importance of intellectual capital is constantly increasing, many organizations face the problems of its management, mostly due to measurement difficulties. This study therefore succinctly examines salient issues on the impact of intellectual capital on the financial performance of corporate establishments in Nigeria. Secondary sources of data collection were employed with the help of the Nigerian Stock Exchange Fact Book. The timeframe for this study was five (5) years and five (5) quoted banks out of the listed banks in Nigeria were used based on purposive sampling. It was discovered that intellectual capital positively and significantly impacted on the financial performance of establishments. Also, physical and structural capitals have positive relationship with the financial performance of the organizations studied. It is therefore advanced that a vibrant and robust training and retraining programmes be put in place to ensure the availability of human resources in the right quantity and quality. Physical and structural capitals' economic and technical capacities should be enhanced to boost the contributions of the human assets. Strategic human resources policies must also be carefully formulated and properly implemented to $x$-ray the possibility of including human assets in the balance sheet of corporate entities and to promote intellectual capital reporting.
\end{abstract}

Keywords: Financial Performance, Human Asset Accounting, Human Capital, Intellectual Capital, Physical Capital, Structural Capital.

\section{Introduction}

It is incontrovertible that the global environment has for several decades witnessed gradual transition from industry based one with a focus on physical assets such as factories, plants, machines and equipments to a very high technology, information and innovation based one with focus on expertise, talents, creativity, skills, dedication and experience of people in the establishment-the organization's human capital. The fundamental difference between the two environments is the nature of their assets. In the former, it is obvious that the physical assets like plants, machinery, materials, equipments are of utmost importance and make up the bulk of the organization's assets while in the latter, knowledge, ability, skills, expertise, experience and attitude of workers are even of greater value(Ekwe,2012).

Again, it is also a known fact that land, labour and capital (financial and physical) were traditionally considered to be the most valuable assets in economics and conventionally, physical assets were considered to be the main determinants of the performance of any economic activity. Although this belief is held over several decades, the unprecedented speed of expansion of science, technology and finally globalization has altered the patterns and structures of the production systems today. The new production systems are driven mainly by technology, knowledge, expertise and relations with stakeholders etc which may collectively be described as intellectual capital (Ahangar, 2011).The new economic system popularly known as the knowledge economy recognizes intangible or intellectual assets as vital resources needed for the survival and sound performance of the organization. 
Manufacturing companies use intellectual capital with physical assets to sharpen their competitive edge (Firer and Williams, 2003). Bornemann et al (1999) stresses that enterprises which have managed their intellectual capital better had achieved stronger competitive advantage than the general enterprises. Intellectual capital management plays an important role on the long term business performance of an enterprise (Brennan and Connell, 2000).Human capital has also been recognized as one of the key determinants of growth today. This applies especially to modern developed economies such as Switzerland, United States of America, China, Japan etc as companies with a large share of unskilled labour have moved to other countries of the world as a consequence of their comparative advantage(Polasek et al,2011).Even though it has been a known fact for years that companies with good intellectual capital perform better, there are not many empirical studies that focus on the impact of human capital solely for developing economies like Nigeria

Intellectual capital has been considered as inalienable and indispensable resource particularly in environments where the source of competitive advantage is strongly based on knowledge and intangible resource. However, conservative accounting practices as opined by Chen, Cheng and Hwang (2005) restrain firms' investments in intellectual capital from being presented in financial statements, resulting in the growing divergence between firms' market and book values. According to Beattie and Thomson (2010), intellectual capital creates company value but generally this value is not recognized in the financial statements of companies. Study conducted by Okwy and Christopher(2010) as cited in Tayib and Salman (2011) reveals that Nigerian Breweries Plc invested more than N88 million in local and overseas training and development of its employees as far back as 1988, in 2006, Unilever invested over N40 million in training and development of its employees, Access Bank Plc in 2007 constructed Access Bank Campus called Access University of Banking Excellence and Wema Bank Plc invested huge amount on policy, training and development of its employees. The intellectual capital (IC) has witnessed rapid growth in recent times with a range of IC measurements and reporting models being developed by academics, consultants and practitioners as argued by Petty et al (2009), there is no generally acceptable basis for valuing intellectual capital. However, the widespread acceptance of intellectual capital has led to the development of appropriate methods of measurement for intellectual capital, since traditional financial tools are not able to capture all of its aspects (Campisi and Costa, 2008; Nazari and Herremans, 2007). Pulic (2000) developed the most popular method that measures the efficiency of value added by corporate intellectual ability (Value Added Intellectual Coefficient-VAIC).VAIC measures the efficiency of three types of inputs: physical and financial capital, human capital and structural capital (Firer and Williams, 2003; Montequin et al, 2006).

Despite the shift towards human capital intensive economy, traditional accounting has continued to focus more on the physical assets in their financial statements to the exclusion of the more important assets-the Human Assets (Armstrong, 2006).Fortunately, human assets belong to group of assets classified as intangible assets because they represent those innate qualities of people which cannot be seen or touched but which are indispensable for organizational success and survival. Notwithstanding the fact that there are accounting treatments for acquired intangible assets in the balance sheet, current financial accounting treats human resource related costs as expenses which reduce profit on the income statement only in the current accounting periods, rather than being reported as assets on the balance sheet which provides future benefits. As a result, management is denied of relevant and timely quantitative data to be able to take vital decisions on human resources.

Various studies have been conducted different parts of the world on the measurements and reporting of intellectual capital and its relevance to the financial performance of companies. Some of these studies were in United Kingdom, United State of America, Malaysia, Sub Sahara Africa, South Africa etc. In Nigeria, apart from the works of Uadiale and Uwuigbe (2011), Suraj and Bontis (2012) and Ekwe (2012), there are no broad and advanced research work on this very important area of Accounting. It is a common knowledge today that most reputable business organizations contract out the process of recruiting and training new employees to human resource consulting firms, usually at a very high fees. Even after recruiting new workers, large sums of funds are further voted for their orientation, training and retention of these workers to enhance their performance and efficiency in the organizations. Even where organizations do not contract out the process of recruiting, huge amount of money and time are expended on advertisement for the vacant positions, interviewing, selection and training of the newly recruited staff. Apparently the reason for the situation above is because there is lack of monetary measurement system for human capital. Where good and reliable system for human capital measurement is developed, there will be a lot of financial savings for the organizations and vital human resource information and policies are preserved. 
This research intends to critically look at intellectual capital, structural capital. Physical capital and the financial performance of corporate establishments in Nigeria using the Value Added Intellectual Coefficient. Also, the study will analytically examine the effects of capital employed efficiency, human capital efficiency and structural capital efficiency on the financial performance indices of the corporate establishments.

\section{Statement of the Research Problem}

The growing importance of human capital to the economic growth and development of business entities at both microeconomic and macroeconomic levels has necessitated the need for a shift of investment decisions to reflect this reality (Flamholtz, 1999).Some schools of thought believed that adequate investments are not being made on intellectual capital in line with its growing importance to the organizations today. Even where substantial investments are made on intellectual capital, the intellectual capital reporting becomes a very challenging task since this very important asset has no place yet in the balance sheets of corporate establishments. Several decisions such as the investment decisions, financing decisions, dividend decisions etc are taken by corporate establishments without placing much premium on the human resources management system which often times leaves the business with much to be desired. Wrong decisions are often made on who to hire or fire, who to train or re-train, who to promote or demote, conditions for placements and remunerations etc. Apparently, the reason for the above is because no generally accepted standard monetary measurement system for human capital which will reflect the actual value of human resources has been developed. If a transparent system of determining human capital value through a well articulated monetary measurement system can be developed, the distortions caused by the exclusion of the human assets from the Balance Sheet could be corrected.

Obviously, there have been some conflicting results on the importance and relationship between intellectual capital and organizational performance especially in Nigeria. While some scholars agree that intellectual capital relates positively and significantly with organizational financial performance and as such accord organizations competitive edge over others(Bornemann et al, 1999 ;Brennan and Connell,2000); others believe that there are no relationships between intellectual capital and organizational performance and that physical assets still maintain the key determinants of organizational financial performance(Wright et al, 1995;Gottfredson,1997; Jensen,1998). Intellectual capital as the knowledge based equity of organizations has attracted a significant amount of practical interest. Although the importance of intellectual capital is constantly increasing, many organizations face the problems of its management, mostly due to measurement difficulties. This study therefore intends to examine the impact of intellectual capital on the financial performance of corporate establishments in Nigeria.

\section{Objectives of the Study}

The main objective of this research is to examine the impact of intellectual capital on the financial performance of corporate establishments in Nigeria. The specific objectives are:

(i)To examine the extent to which human capital affects the financial performance of the banks in Nigeria.

(ii)To ascertain the extent to which structural capital affects the financial performance of the banks in Nigeria

(iii)To determine the extent to which physical capital affects the financial performance of the banks in Nigeria

\section{Research Questions}

From the statement of research problem and the objectives of the study, the following research questions will guide the research work:

(i)To what extent does the human capital affect the financial performance of the banks?

(ii)To what extent does the structural capital affect the financial performance of the banks?

(iii)To what extent does the physical capital affect the financial performance of the banks?

\section{Research Hypotheses}

The following hypotheses are formulated on the subject matter:

$\mathrm{HO}_{1}$ : There is no significant relationship between a bank's human capital and its financial performance.

$\mathrm{HO}_{2}$ : There is no significant relationship between a bank's structural capital and its financial performance.

$\mathrm{HO}_{3}$ : There is no significant relationship between a bank's physical capital and its financial performance.

\section{Significance of the Study}

This research is expected to contribute significantly and originally to existing body of knowledge. It will be of great importance to a number of parties: human resources managers, professional accounting and regulatory bodies, labour unions, corporate entities, the academia, financial and investment analysts, governments etc. 
Where ROA=Profitability as measured by Returns on Assets or Asset-Turnover Ratio

ROE $=$ Profitability as measured by Returns on Equity

$\mathrm{GR}=$ Growth in sales as measured by the ratio of the current year's excess sales to previous year's sales.

HCE=Human Capital Efficiency

SCE=Structural Capital Efficiency

$\mathrm{CEE}=$ Capital Employed Efficiency

$\mathrm{PC}=$ Physical capital

DER=Debt-equity ratio

$\mathrm{ATO}=$ Asset-turnover ratio

VAIC $=$ Value Added Intellectual Co-efficient

\section{Model One}

Table 1: Model Summary

\begin{tabular}{|l|l|l|l|l|}
\hline Model & $\mathrm{R}$ & $\mathrm{R}$ Square & $\begin{array}{l}\text { Adjusted } \\
\mathrm{R} \text { Square }\end{array}$ & $\begin{array}{l}\text { Std. Error of the } \\
\text { Estimate }\end{array}$ \\
\hline 1 & $1.000^{\mathrm{a}}$ & 1.000 & 0.000 & 0.000 \\
\hline \multicolumn{5}{|c}{ a Predictors: (Constant), PC, CEE, HCE }
\end{tabular}

Table 2: ANOVA ${ }^{b}$

\begin{tabular}{|ll|l|l|l|l|l|}
\hline Model & & $\begin{array}{l}\text { Sum of } \\
\text { Squares }\end{array}$ & df & Mean Square & F & Sig. \\
\hline 1 & Regression & 0.000 & 3 & 0.000 & 0.000 & $0.000^{\mathrm{a}}$ \\
& $\begin{array}{l}\text { Residual } \\
\text { Total }\end{array}$ & 0.000 & 0 & 0.000 & & \\
\hline \multicolumn{6}{|c|}{ a Predictors: (Constant), PC, CEE, HCE } \\
b Dependent Variable: ROA
\end{tabular}

Table 3: Coefficients ${ }^{\mathrm{a}}$

\begin{tabular}{|ll|l|l|l|l|l|}
\hline \multicolumn{2}{|l|}{} & \multicolumn{2}{|l|}{$\begin{array}{l}\text { Unstandardized } \\
\text { Model }\end{array}$} & $\begin{array}{l}\text { Standardized } \\
\text { Coefficients }\end{array}$ & $\mathrm{t}$ & Sig. \\
\hline & & $\mathrm{B}$ & Std. Error & Beta & $\mathrm{B}$ & Std. Error \\
\hline 1 & (Constant) & 0.394 & 0.000 & & 0.000 & 0.000 \\
& HCE & 0.002 & 0.000 & 0.263 & 0.000 & 0.000 \\
& CEE & 1.589 & 0.000 & 0.966 & 0.000 & 0.000 \\
& PC & 0.057 & 0.000 & 1.819 & 0.000 & 0.000 \\
\hline
\end{tabular}

a Dependent Variable: ROA

In table 1 the value of $\mathrm{R}$, Coefficient of Correlation, is 1.000 which indicates a perfect relationship between ROA and the independent variables PC, CEE and HCE while the coefficient of determination $\left(\mathrm{R}^{2}\right)$ is also $1.000 . \mathrm{R}^{2}$ measures the proportion of variation that is explained by the independent variables in the regression model (Berenson and Levine, 1996). It lies between 0 and 1; the closer it is to 1, the better is the fit. A value of zero, on the other hand, would indicate that the model fails to accurately model the dataset (Gujarati, 2003). The value of the coefficient of determination is often used in deciding whether or not to continue the analysis of a particular set of data (Curwin and Slater, 2002). From the table above, the result shows that about $100 \%$ of ROA is accounted for by the independent variables. Correlation coefficient measures the strength and the direction of a linear relationship between two or more variables. A correlation between 0.81 to 0.99 is generally described as very high (almost perfect), between 0.61 to 0.80 is described as substantial/high. Between 0.41 to 0.60 is moderate and between 0.21 to 0.40 is low whereas a correlation less than 0.20 is negligible or insignificant (Adefila, 2008).

Table 2 shows the amount of variation in the regression model. The value of $F$ is $0.000 . F$ test is the ratio of the variance due to a regression divided by the error variance. It measures the overall fit of a regression. The regression model is significant at 0.000 . This means $0 \%$ significant level and $100 \%$ confidence level. From 3 , the result shows that the coefficient estimate for HCE, CEE, and PC are $0.002,1.589$ and 0.057 respectively. The T values for the independent variables are all zeros. 
This implies that there is a positive relationship between ROA and HCE, CEE, and PC. This means that there is a significant positive relationship between a bank's human capital and its financial performance.

\section{Model Two:}

Table 4: Model Summary

\begin{tabular}{|l|l|l|l|l|}
\hline Model & $\mathrm{R}$ & R Square & $\begin{array}{l}\text { Adjusted } \\
\text { R Square }\end{array}$ & $\begin{array}{l}\text { Std. Error of } \\
\text { the Estimate }\end{array}$ \\
\hline 1 & $1.000^{\mathrm{a}}$ & 1.000 & 0.000 & 0.000 \\
\hline \multicolumn{5}{|c}{ a Predictors: (Constant), HCE, CEE, PC }
\end{tabular}

Table 5: ANOVA ${ }^{\text {b }}$

\begin{tabular}{|c|c|c|c|c|c|c|}
\hline Model & & $\begin{array}{l}\text { Sum of } \\
\text { Squares }\end{array}$ & df & $\begin{array}{l}\text { Mean } \\
\text { Square }\end{array}$ & $\mathrm{F}$ & Sig. \\
\hline 1 & $\begin{array}{l}\text { Regression } \\
\text { Residual } \\
\text { Total }\end{array}$ & $\begin{array}{l}0.009 \\
0.000 \\
0.009\end{array}$ & $\begin{array}{l}3 \\
0 \\
3\end{array}$ & $\begin{array}{l}0.003 \\
0.000\end{array}$ & 0.000 & $0.000^{\mathrm{a}}$ \\
\hline
\end{tabular}

a Predictors: (Constant), HCE, CEE, PC

$b$ Dependent Variable: ROE

Table 6: Coefficients ${ }^{\mathrm{a}}$

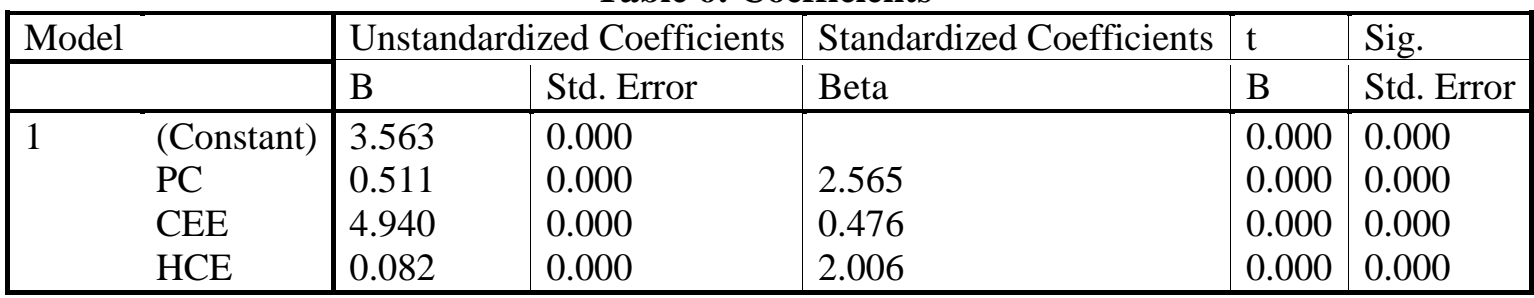

a Dependent Variable: ROE

In table 4 the value of $\mathrm{R}$, Coefficient of Correlation, is 1.000 which indicates a perfect relationship between ROE and the independent variables PC, CEE and HCE while the coefficient of determination $\left(\mathrm{R}^{2}\right)$ is also 1.000 . This table is same as table 1.In table 5, the value of $\mathrm{F}$ is the same as that of table 2 which measures the overall fit of a regression. The regression model is significant at 0.000 . This means $0 \%$ significant level and $100 \%$ confidence level. From table 6,the result shows that the coefficient estimate for PC,CEE and HCE are 0.511,4.940 and 0.082 respectively. The $\mathrm{T}$ value as for the independent variables are all 0 . This implies that there is a positive relationship between ROE and HCE, CEE, and PC. This means that there is a significant positive relationship between structural capital and financial performance of banks in Nigeria.

Model Three

Table 7: Model Summary

\begin{tabular}{|l|l|l|l|l|}
\hline Model & $\mathrm{R}$ & $\mathrm{R}$ Square & $\begin{array}{l}\text { Adjusted } \\
\mathrm{R} \text { Square }\end{array}$ & $\begin{array}{l}\text { Std. Error of the } \\
\text { Estimate }\end{array}$ \\
\hline 1 & $1.000^{\mathrm{a}}$ & 1.000 & 0.000 & 0.000 \\
\hline \multicolumn{4}{|c|}{ a Predictors: (Constant), HCE, CEE, PC }
\end{tabular}

Table 8:ANOVA ${ }^{\mathrm{b}}$

\begin{tabular}{|ll|l|l|l|l|l|}
\hline Model & & Sum of Squares & df & Mean Squarae & $\mathrm{F}$ & Sig. \\
\hline 1 & Regression & 0.069 & 3 & 0.023 & 0.000 & $0.000^{\mathrm{a}}$ \\
& Residual & 0.000 & 0 & 0.000 & & \\
& Total & 0.069 & 3 & & & \\
\hline \multicolumn{5}{|c|}{ a Predictors: (Constant), HCE, CEE, PC } \\
\multicolumn{5}{r|}{ b Dependent Variable: GR }
\end{tabular}


Table 9: Coefficients ${ }^{\mathrm{a}}$

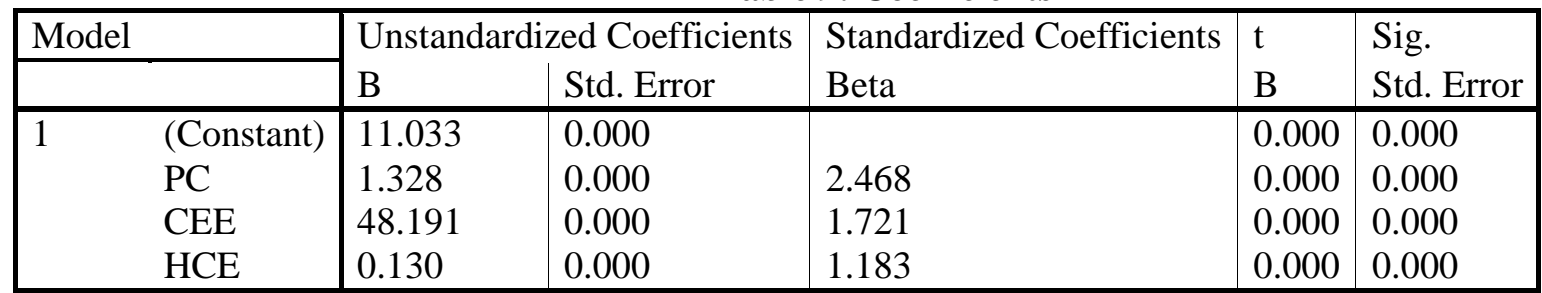

a Dependent Variable: GR

In table 9, the result shows that the coefficient estimate for HCE, CEE, and PC are 0.130, 48.191 and 1.328 respectively. The $\mathrm{T}$ value as for the independent variables are all 0 . This implies that there is a positive relationship between GR and HCE, CEE, and PC. This means that there is a significant positive relationship between physical capital and financial performance of banks in Nigeria

\section{Conclusion}

The importance of human assets cum intellectual capital to the survival and sound performance of every organization cannot be overemphasized. In fact, the human resource is one of the most vital assets of every organization. Intellectual capital relates positively and significantly with organizational financial performance and as such accord organizations competitive edge over others. Intellectual capital as the knowledge based equity of organizations has attracted a significant amount of practical interest as a result of its significance in the running of the business. It was discovered that intellectual capital positively and significantly impacts on the financial performance of corporate establishments in Nigeria. Also, physical and structural capitals have positive relationship with the financial performance of the organizations studied. Physical and structural capitals' economic and technical capacities should be enhanced to boost the contributions of the human assets to organizational financial performance. Also, it is suggested that a vibrant and robust training and retraining programmes be put in place to ensure the availability of human resources in the right quantity and quality.Strategic human resources policies must also be carefully formulated and properly implemented to x-ray the possibility of including human assets in the balance sheet of corporate entities and to promote intellectual capital reporting.

\section{References}

Adefila, J.J. (2008). Research Methodology in Behavioural Sciences. Kaduna: Apani Publication.

Ahangar,R.G.(2011):'The Relationship between Intellectual Capitals and Financial Performance: An Empirical Investigation in an Iranian Company"African Journal Of Business Management Vol.5 No.1 PP.88-95.

Amah, G.A.N.(2006):"Assessing the Impact of Human Resource Costing and Accounting on Corporate Valuation Decisions" Abia State University-Nigeria.

American Accounting Association Committee (1973):'Report on Human Resource Accounting "The Accounting Review Vol.48

Armstrong,M.(2006):A Hand Book of Human Resource Management Practice.10 ${ }^{\text {th }}$ ed.,London:Kojan Page

Beattie,V. and Thomson,S.(2010):Intellectual Capital Reporting: Academic Utopia or Corporate Reality in a Brave New World? Institute of Chartered Accountants of Scotland(ICAS),Edinburgh. ISBN 9781904574637

Berenson, M.L. and Levine, D.M. (1996). Basic Business Statistics: Concept and Application (6 ${ }^{\text {th }}$ ed.). New Jersey: Prentice Hall

Bornemann,M.(1999):"Empirical Analysis of the Intellectual Potential of Value Systems in Austria According to the VAIC"Journal of Intellectual Capital Vol.3No.5 Pp. 16-20

Brennan,N. and Connell(2000):'Intellectual Capital: Current and Policy Implications".Journal of Intellectual Capital Vol.1 No.3 Pp.156-165

Bullen,M. and Eyler,K(2011):"Human Resource Accounting and International Developments;Implications for Measurement of Human Capital"Journal of International Business and Cultural Studies Campisi,D. and Costa,R.(2008):"A DEA-Based Method to Enhance Intellectual Capital Management"Journal of Knowledge and Process Management.Vol.15 No.3 Pp.170-183 
Chen,M.C.;Cheng,S.J. and Hwang,Y.(2005):"An Empirical Investigation of the Relationship between Intellectual Capital and Firm's Market Value and Financial Performance"Journal of Intellectual Capital. Vol.6No.2 Pp.159-169

Curwin, J. and Slater, R. (2002).Quantitative Methods for Business Decisions (5th ed.). London: Thomson Learning.

Ekwe,M.C.(2012):Human Resource Accounting:The Relationship between Intellectual Capital and Financial Performance.Universty of Nigeria,Nsukka

Firer,S. and Williams,M.(2003):Intellectual Cpital and Traditional measures of Corporate Performance.Journal of Intellectual Capital.Vol.4 No.3 Pp. 48-60

Flamholtz,E,G,(1999):Human Resource Accounting:Advances,Concepts,Methods and Applications.Academic Publishers

Gottfredson,L.S.(1997):’Why Matters:The Complexity of Everyday Life".Intelligence,Vol.24 No.1 Pp.79-94

Gujarati, D.N. (2003). Basic econometrics (4th ed.). Boston: McGraw-Hill

Jensen,A.R.(1998):The Factor:The Science of Mental Ability.Westport,CT:Praeger

Kavida,V. and Sivakoumar,N.(2008):Corporate Governance in Knowledge Economy-The Relevance of Intellectual Capital from www,ssrn.com/id1011981

Nazari,A. and Herremans(2007):"Extended VAIC Model:Measuring Intellectual Capital Components"Journal of Intellectual Capital Vol.8 No.4 Pp.595-609

Petty,R. and Guthrie(2000):"'Intellectual Capital Literature Review;Measurement.Reporting and Management"Journal of Intellectual Capital.Vol.1 No.2 Pp.155-176

Polasek,W., Wolfgang S., and Richard S.(2011):"Human Capital and Regional Growth in Switzerland"Review of Economic Analysis

Pulic, A.(2000):"VAIC-An Accounting Tool for IC Management"International Journal of Technology Management Vol.20 Nos.5,6,8 Pp.702-714

Tayib,M. and Salman,R.T.(2011):Intellectual Capital Reporting in Nigeria: A Way Forward from www.aibuma.org/proceedings

Wright,P.M.,Kacmar,K.M.,McMahan,G.C. and DeLeeuw,K.L.(1995):’’P= f(M¥A)Cognitive Ability as a Moderator of the Relationship between Personality and Job Performance".Journal of Management Vol.21 No.6 Pp.1129-1139 